\title{
Maurer, Salum e a Romanística: pioneirismo, sabedoria e humildade
}

\author{
IZIDORO BLIKSTEIN
}

\section{$\mathrm{P}$} arece haver unanimidade quanto ao indiscutível papel de cilncia piloto que a lingüística desempenha no âmbito das ciências humanas: com efeito, ao desvendar o funcionamento da linguagem, a lingüística oferece um eficaz aparelho teórico metodológico para a análise do discurso, com fecundos desdobramentos para as mais variadas áreas como ensino de línguas, literatura, poética, comunicaçáo, antropologia, filosofia, psicologia etc. Pois bem, se lembrarmos que os introdutores da ciência lingüística na Faculdade de Filosofia, Letras e Ciências Humanas (a antiga Faculdade de Filosofia, Ciências e Letras, lá da saudosa rua Maria Antônia), foram os professores Theodoro Henrique Maurer Jr. e Isaac Nicolau Salum, já teremos falado um pouco da importância destes dois grandes mestres para a Universidade de Sáo Paulo. O papel de Maurer ou de Salum, porém, vai além: as suas presenças e atuações na docência, pesquisa, publicaçōes e formação de especialistas foram muito mais largas e abrangentes, à medida em que a área de atuação dos mestres - Filologia Românica, ou melhor, a Lingüística Românica, ou melhor ainda, a Romanística - tem sido um dos pilares do curso de Letras.

E tudo começou em 1947, quando o professor Maurer - ao retornar da Universidade de Yale, onde, como bolsista da Rockfeller Foundation, realizou estudos de Lingüísticas Indo-Européia, Sânscrito e Hitita, tendo sido aluno de eminentes lingüistas como Bloomfield e Sturtevant - foi contratado para reger a cadeira de Filologia Românica em nossa Faculdade, tendo como assistente o professor Salum. A essa altura, ambos já tinham uma respeitável experiência de ensino de línguas românicas e clássicas em faculdades, cursos de teologia e na escola secundária. Cabe observar que além do latim, do grego e das línguas românicas, Maurer e Salum eram profundos conhecedores da Bíblia e da língua hebraica, devido à sua formação religiosa de orientaçăo presbiteriana. Tais qualidades, aliadas à cultura e à erudiçáo (com sólidos conhecimentos da história e da geografia do mundo românico) explicam a consistência e a abrangência da Filologia Românica que, nas mãos de 
Maurer e Salum, não se restringiram ao estudo dos textos antigos (filblogo, nunca é demais lembrar, é o amigo do texto), mas ampliaram a sua perspectiva, à medida em que, com a utilização de método históricocomparativo, passaram a analisar e a descrever a estrutura e a evoluçáo das línguas românicas a partir do latim vulgar. Além da Filologia (o que não era pouco), os alunos praticavam a Lingüística Romdnica que, como explicaçáo mais ampla e satisfatória dos fatos lingüísticos, exigiu a contribuição de outras áreas, como a literatura, a história, a geografia, a sociologia etc. A Lingüística Românica tornou-se uma Romantstica, isto é, uma ciência geral do mundo românico, sendo o método histórico-

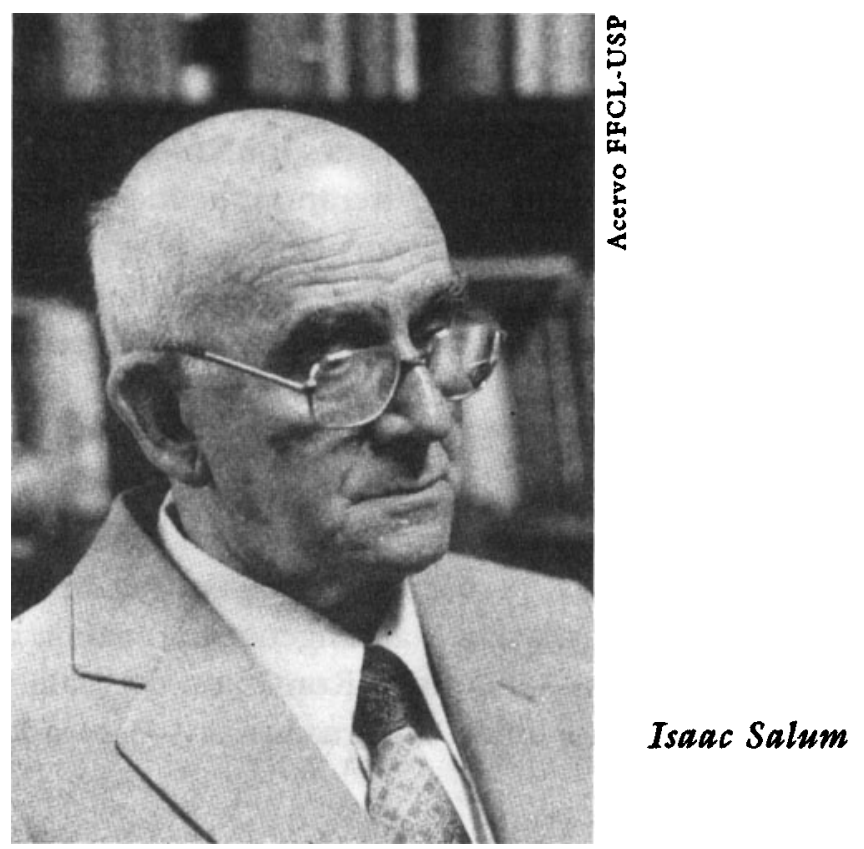

comparativo a sua ferramenta básica. $O$ entusiasmo com o método, levou o professor Maurer a criar (sem ônus para a Universidade) o curso de Lingüística Indo-Européia, que consistia na descriçăo da estrutura e da evolução das línguas indo-européias (grego, latim, sânscrito etc.). A partir daí, foi apenas um salto para a Lingüística Geral, antes mesmo que essa disciplina se tornasse obrigatória no currículo mínimo de Letras. $O$ pioneirismo de Maurer e Salum aparece também na própria concepçáo do objeto de seu ensino: a sua visão dinâmica e culturalista da linguagem, levou-os a conceituar o latim vulgar - contrariamente a toda a tradiçáo européia - como o latim plebeu e rístico, falado pelas classes que latinizaram o Império Romano (soldados, colonos, mercadores 
etc.), um latim dinâmico, e não um latim estático, falado por classes médiaus. Tal concepçáo mudava e ampliava muito a perspectiva de análise, exigindo uma abordagem sócio-lingüística, o que era um avanço para os anos 50: um desdobramento dessa percepcáo mais arejada, foi a necessidade do estudo de uma língua românica meio esquecida pelos europeus, a saber, o romeno.

As idéias pioneiras de Maurer e Salum, além, naturalmente, de suas monumentais cultura e erudição, estão registradas num alentado

Theodoro Maurer

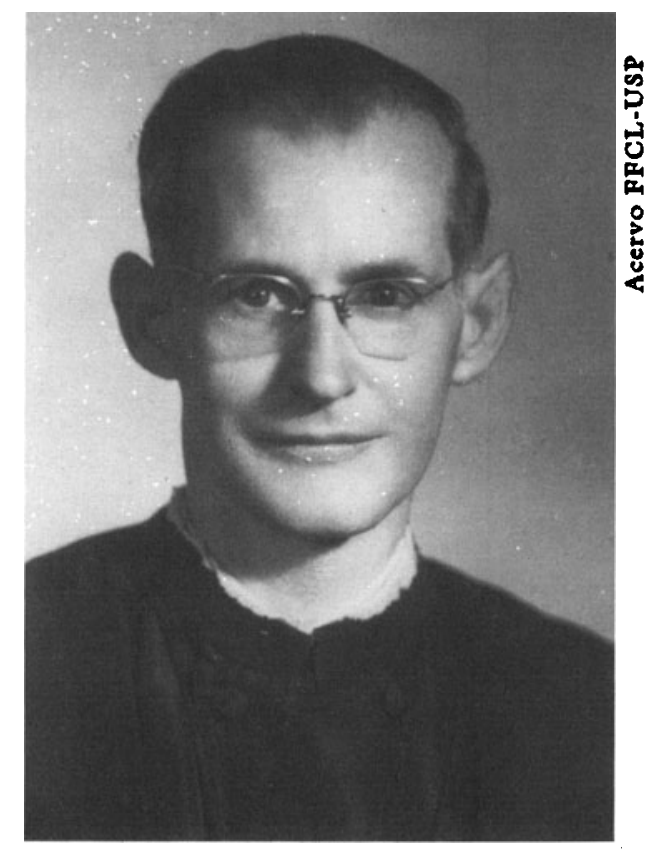

conjunto de publicaçōes, entre livros, artigos, teses dentre os quais, citaríamos

- de Theodoro Henrique Maurer Jr.:

A unidade da România ocidental. Sáo Paulo, 1951 (Boletim ne 118 da Faculdade de Filosofia, Ciências e Letras da USP);

Gramática do latim vulgar. Rio, Liv. Acadêmica, 1959.

O problema do latim vulgar. Rio, Liv. Acadêmica, 1962.

- de Isaac Nicolau Salum:

A problemática da nomenclatura semanal romdnica. Sáo Paulo, FFLCH/USP, 1968.

Cabe também assinalar que nossos mestres desenvolveram ativi- 
dades e publicaçōes em várias outras áreas, como traduçōes e comentários de textos bíblicos, trabalhos de análise textual e literária - caso das abordagens sintático-estilísticas de textos literários, uma notável e perspicaz operação de engenharia textual elaborada pelo professor Salum além de importante atuação social no campo do cooperativismo.

O professor Maurer tornou-se catedrático de Filologia Românica em 1952, aposentado-se em 1967, quando o sucedeu o professor Salum, que permaneceu como titular da área até a aposentadoria, em 1983. Ambos, infelizmente, já faleceram, mas deixaram a sua marca indelével de cultura de erudiçáo e... sobretudo de humanismo e de humildade.

Izidoro Blikstein é professor do Departamento de Iingüística da Faculdade de Filosofia, Letras e Ciências Humanas da USP. 